\title{
Sectarian Crisis in Northern Nigeria: Case Study of Kaduna State (2007-2016)
}

\author{
Eze-Michael, Ezedikachi. N \\ Department of Political Science and Public Administration \\ Babcock University, Nigeria
}

Tel: 80-613-211-40Ｅmail: eze-michaele@babcock.edu.ng; akwarandue@yahoo.com

Received: July 10, 2017 Accepted: August 2, $2017 \quad$ Published: September 12, 2017

doi:10.5296/ijssr.v5i2.11231ＵRL: http://dx.doi.org/10.5296/ijssr.v5i2.11231

\begin{abstract}
Sectarian crisis has been said to have erupted from groups with different ideological values and perspectives and had resulted into conflicts and brought about sectarian crisis especially in the northern Nigeria. The study examined the various causes of sectarian crisis in northern Nigeria, which included religious fundamentalism, religious extremism, and political manipulations. The study examined the effect of sectarian crisis in northern Nigeria with Kaduna state used for the case study. It was structurally analyzed with the use of quantitative method due to the nature of the research. The study developed fifteen (15) research questions, which were administered to 2 local government areas in Kaduna state namely Jema'a and Zagon kataf. Both primary and secondary data were used as sources of data. For primary sources data was gotten from the field work where research questionnaires were distributed and, for the secondary sources, data was gotten from journals, articles, published and unpublished books, libraries, works from the existing literature related to this study as well as from the internet. While the simple percentage technique was used in organizing and presenting the data collected. The data analysis revealed that sectarian crisis created ethnic differences and socio-economic problems. The study recommended that for sectarian crisis to be prevented, an elaborate process of depoliticizing ethnic groups must be put in place. The government also should take measures to shutdown religious group crisis by promoting peace and unity in the society. By this northern Nigeria will experience peace, oneness, good security and national Unity.
\end{abstract}

Keywords: Sectarian, Crisis, Northern Nigeria, Kaduna State, Religion 


\section{Introduction}

\subsection{Background to the Study}

In general terms, sectarian crisis erupts particularly from groups and collective individuals and it usually results into conflicts if not properly managed or regulated by the society. Several violent techniques have often been employed to pursue and defend certain claims and interests by various competing groups in the society. In other words, violence especially those expressed by groups are always precipitated by political, economic and socio-cultural criticism which are not promptly and also properly resolved. Historically, under a variety of social and political systems and contexts, people in almost every part of the world have engaged in conflicts and violent expressions, they have also waged wars using a variety of techniques of struggle. In modern times, instances of conflicts and expressive violent outbursts have become more crowded on a diverse range of issues ranging from politics, economy, religion, ethnicity, ideology and extreme forms of terrorism.

Sectarian crisis in northern Nigeria has flared up periodically over the last 30 years, mainly in the form of urban riots; it has Muslims against Christians and experiences of confrontations between different Islamic sects. Within the last two decades Nigeria has witnessed a variety of turbulence, some of which have threatened the existence of the country as a nation. Some of this turbulence could be described as intra-religious while the others are inter-religious. There are others that are more of political in nature than religious even though some individuals may see them as religious simply because each group involved come from different religious backgrounds.

In northern Nigeria, sectarian crisis has become more or less like a monthly affair, causing devastating consequences. It is therefore against these backdrops that the study intends to examine cases of sectarian crisis in northern Nigeria using Kaduna state as case study from 2007 to 2016.

Sectarian crisis in Nigeria has presented many challenges that bother on security and the corporate existence of the country which is the fundamental reason for the adoption of a federal system. A major source of what we now see as ethno-religious conflicts in Nigeria has to do with the accusations and allegations of neglect, domination, exploitation, victimization, discrimination, marginalization nepotism and religious intolerance. What this means is that conflicts usually occur when deprived groups and individuals attempt to increase their share of power and wealth or put differently, to modify the dominant values, norms, beliefs and ideologies. Thus, in Nigeria, there seems to be a divisive interplay of politics, ethnicity and religions, which has consequently led to the rising jingoism and militancy of various ethnic and religious movements. For the purpose of this study and as stated above, the geographical area is Kaduna state, which is located in the northern part of Nigeria. The time frame of the study is 2007 - 2016. The study is to find out the immediate and remote causes of sectarian crisis in the northern Nigeria and take a critical view on how sectarian crisis has affected the northern Nigeria.

It has become abundantly clear that no nation can survive without exhibiting peaceful 
coexistence and religious tolerance. Therefore, this study will also provide useful information and operational framework which government, economic planners, administrators, public office holders, policy makers, academicians, students, and the general public could utilize in understanding issues surrounding sectarian crisis in northern Nigeria. The results from this study are expected to be of benefit to government, government, politicians, civil society organizations, NGOs, National Economic Council, political parties, students and the nation at large.

The study will help in solving and also preventing future occurrence of sectarian crisis in northern Nigeria and the nation as a whole. The study will assist the community development association on peace building initiatives that would help in bringing about peaceful coexistence.

\section{Literature Review and Theoretical Framework}

\subsection{The Concept of Sectarian Crisis}

Sectarian crisis is termed as any form of intolerance, discrimination or hatred arising from attaching relations of inferiority and superiority to differences between subdivisions within a group commonly found among different religious denominations, ethnic identity and factions of political movements. Generally and according to Weidmann (2012), sectarian crisis can be viewed from two perspectives namely the micro and macro level violence. Macro level violence sees violence as a result of change to the ethnic map while the micro level attributes violence to hostility between neighbors that are of different ethnic group.

Conflict is when two or more values, perspectives and opinions are clashing in nature and have not been aligned and agreed upon (Bagaji, 2012). Where conflicts regularly occur, there is the tendency for it to affect the socio-economic development of such particular and geographical area. To understand this concept of socio-economic development, it is imperative we define development. Generally, development is referred as a state where something moves from an unpalatable situation to palatable situation. Development also could mean the improvement in people's lifestyle through improved education, income, skills development and employment (Adeniyi, 1993). It is the process of economic and social transformation that is based on cultural and environmental factors. Socio-economic development therefore is the process of social and economic development in a society. It is measured with indicators, such as Gross Domestic Product (GDP), life expectancy, literacy and levels of employment (Okonjo-Iweala \& Osafo-Kwaako, 2007).The need for a religious tolerance among the different religious adherents' remains relevant in the sustenance of the socio-economic development of a country like Nigeria.

Salawu (2010) gave a brief explanation of existing literature on the remote socio-political, economic and governance factors that drive religious violence in Nigeria. To him government neglect, oppression, dominance, exploitation, victimization, discrimination, marginalization, nepotism and bigotry are some of such factors. In his study, Kwaja (2009) also identified weakness of the institutions of the state in terms of their ability and capacity to manage multiplicity, corruption, rising inequality between the rich and poor, gross violation of human 
rights, environmental degradation, contestations over land, among others, as underlying causes of violent conflicts in Nigeria. Achunike (2008) opined that the wrong views of other people's religion and faith, wrong religious orientation, low literacy level of religious adherents, selfishness on the part of religious personalities and their leaders, pervasive poverty, and government involvement in religious matters, among others are responsible for interreligious conflicts in Nigeria.

\subsection{Sectarian Crisis in Northern Nigeria}

Danjibo (2016) revealed that, historically, there is the issue of unhealthy rivalry between Islamic movements whose sponsors can be linked to transnational bodies, especially in the Middle East and Asia. A lot of Muslims have been brainwashed and believe that dying in the course of defending Islam would make them earn the status of martyr. Therefore they are inclined to sacrifice their lives through violent means.

There is also the "Almajeri syndrome”. A large army of unemployed vagabonds roam around the streets paying the dues of discipleship by way of begging and scavenging. These set of groups are ready to get involved and even perpetrate violence for a token. Danjibo, (2016) said and I quote:

"I visited a Catholic hospital in Kaduna shortly after one of the religious crises occurred. I met some admitted Almajeri who had been seriously injured during the crisis. One of them who had lost his limb was in deep pain and was crying with the words: "why should this happen to me? Now I have lost my life because of N200”.

Upon further inquiry, the victim revealed that a large number of them (the Almajeri) were given some money to go perpetrate violence. Perhaps the most viable explanation for the recurrent violence, including religious and sectarian violence, is the failure of good governance in Nigeria. As Usman (2014) revealed that the youths that are mostly engaged in acts of violence or serve as an army of this sectarian violence are usually the victims of bad governance and acute corruption that has eaten deep into the Nigerian polity.

\subsubsection{Sectarian crisis in Kaduna state}

Kaduna state since its creation has attracted wide range of immigration from different parts of the country and beyond. This makes it a complex heterogeneous city, thus provoking interpenetration across ethnic and religious lines. Alisan (2000) reported that Kaduna state since independence has grown to become one of the most important cities in northern Nigeria. Also, because of its political and strategic status, it became the military and police Headquarters of northern Nigeria, where the top brass of armed forces in the north are residents. It has the highest concentration of military institutions in northern Nigeria.

Yahaya (2014) confirmed that Kaduna state is now divided into two settlements where Christians dominate the southern part of the state and Muslims occupy the northern part of the state. People have taken undue advantage of this dominance in a particular section to foment ethno-religious conflicts. Kaduna which used to be relatively a peaceful town in the past, has witnessed a circle of sectarian violence, which has singled it out as one of the most volatile 
cities in northern Nigeria of today (Makarfi, 2004). Against these backgrounds, there have been opposing relationships between the two dominant religions, Christianity and Islam, in the socioeconomic and political affairs of the state. This further reveals that the subsequent upheavals in the state often identified as ethno-religious conflicts from 1980 to date have political, social, ethnic and religious undertones.

Yahaya (2014) listed some of the identified records of ethno-religious conflicts fact files where lives and property worth millions of naira were lost in some towns and villages of Kaduna states include the followings:

1. The Ahmadu Bello University Zaria, Muslims and Christians student clashed in 1977-78 over ideological differences was the first ethno-religious conflict recorded in Kaduna state. The conflict came up when the Kegites club was celebrating the restoration of the Blackman's pride, and chose palm wine as one of the symbols of their rituals. As part of the rituals, members were expected to drink a lot of palm wine. However, the celebration did not go down well with the Muslim Students Society of the University, who claimed that the behavior of the Kajes was the height of depravity, and since they as Muslims were prohibited from consuming alcohol, the Kegites had no right to flaunt this decadence in their face. They later and also argued that the glasses used by the Kegites were bound to be used by Muslim Students in the dining hall. Thus, as soon as the Kegites party got underway, some members of the Muslim Students stormed the hall and organized a violent disruption of the Kegites' activities. Many Kegites were wounded in the process. The Muslim students went on further rampage, damaging other university buildings in the process.

2. Kassiim (1982) reported the October, 1982, Maitatsine religious conflict in Rigasa, Kaduna state which virtually set Kaduna metropolis up in flames. The Maitatsine sect had at times clashed with orthodox Muslims based on the interpretation of the Holy Qur'an. One of such clashes took place in Rigasa with mainly Muslim indigenous settlers. The conflict was over their mode of worship. The Maitatsine sect had insisted that the orthodox Muslims in the congregational prayer should not face Kaaba, with the orthodox Muslims.

3. There was also the Fun Times Magazine religious conflict of April 1993 in Kaduna. Sabine (1993: 7) reported that the Fun Times, a general interest magazine published by Nigeria’s Daily Times Groups, had carried a blasphemous article on Prophet Mohammad.

4. Otuwoyo (2001) reported another religious conflict which took place in October 2001. The conflict resulted to the burning down of some churches at Hayin Banki in Kaduna metropolis. On the day of the conflict, two churches at different locations were allegedly burnt down in a Muslim-dominated area. The Kaduna state government however claimed that the fire was either as a result of an electrical fault but that armed robbers and thieves set them ablaze. The Network of Pastors, however, faulted government's explanation on the following grounds: that it was most improbably that on one particular night, only churches which were at different 
locations would be singled out for an electrical fault that would destroy and set them ablaze; the Muslims were alleged to have done that. At the period of this attack, it was alleged that Muslims attempted to set ablaze Rhema Living Word Church at Kabala Costain, using petrol that they siphoned out of a generator. They allegedly set ablaze the wood near the generator. The flame attracted neighbors who rushed out to put off the fire (The News, November 5, 2001:22).

5. Sani (2007: 110-111), reported another religious conflict in Kaduna over a Thursday blasphemous newspaper article on Prophet Muhammad and a protest against the Miss World pageant in Nigeria between November 21 and 24, 2002. On Wednesday, November 29, 2002, Muslim adherents caused great commotion in Kaduna over the Daily Newspaper story which they described as satanic and blasphemous. The offending article titled, “The World at their Feet”, was written by Isioma Daniel. The Muslims said paragraph five of the first page of Daniel's write-up was an insult. The offending commentary which was likened to Salman Rushdie's satanic verses according to Sani (2007:110) reads: As the idea became a reality, it also aroused dissent from many group of people. The Muslims thought it was immoral to bring 92 women to Nigeria and ask them to revel in vanity. What would Mohammed think?

The riot and violence witnessed attracted a 24 hour curfew that was imposed on the three affected areas namely Zango kataf, Jaba kaura and Jema in a local government. The governor said this can be traced back to the post election violence of 2011 which led to the Fulani herdsmen's' loss of cattle and avengers towards the southern Kaduna local government areas. This riot led to the attack of four local government areas, where 808 people lost their lives ,53 people were injured, 1422 houses were affected, 16 churches, 19 shops and one primary school were destroyed (Premium Times, January 13 2017).

\subsubsection{Causes and Consequences of Sectarian Crisis in Northern Nigeria}

Religious intolerance, fundamentalism and extremism are deliberately chosen to kick-start discussions on the drivers of religious violence in Nigeria because they form the base and sub-structure upon which other sources of sectarian violence and super-structure rest. Religious intolerance has been defined as 'hostility towards other religions, as well as the inability of religious adherents to harmonize between the theories and the practical aspect of religion' (Balogun, 1988). It encompasses bigotry, which is the obstinate and intolerant devotion to one's opinions and prejudices, especially the exhibition of intolerance and animosity toward persons of differing beliefs (Baird \& Rosenbaum, 1999).

Komonchak, Collins and Lane (1996:411) view religious fundamentalism from three perspectives: from a cognitive understanding where the word is associated with a closed personality type that expresses exclusivity, particularity, literality and moral rigor; from a cultural theological viewpoint, where the word expresses opposition to religious and cultural liberalism in defense of orthodoxy and religious traditions; and from a social movement perspective, where it denotes organizational and ideological uniqueness from other types of religious movements. Ultimately therefore, religious fundamentalism is a religious movement 
that promotes the literal interpretation of, and strict adherence to religious doctrine, especially as a return to orthodox scriptural prescriptions and doctrinal originality. It seeks strict adherence to the orthodox principles of particular faiths as in the case of Nigeria, Christianity and Islam and abhors modernism with its propensity to adulterating and diminishing original doctrinal principles. Religious fundamentalists, therefore, place great emphasis 'on right doctrine and the necessity of organized warfare against the forces of modernism' (Komonchak, Collins, \& Lane, 1996:411).

Religious intolerance and fundamentalism may not necessarily entail violence; however, it is the extreme manifestation of intolerance and fundamentalist ideals that embraces violence. Religious extremists are therefore religious fundamentalists, who take religious conservatism and intolerance to an unreasonable extent, by manifesting violence against those who hold contrary religious views. Religious extremists take the position that if others do not follow their ways, they will be damned (Religious extremism 2011). They abhor the preaching of other faiths and resort to violence to stop it. They insist that their religious doctrines must be universally entrenched by brute or force, while the political, social and economic systems must conform to their religious tenets. Religious extremism does not admit of any compromise with social change, particularly that which contradicts religious orthodoxy. In terms of hierarchy, therefore, religious extremism is the farthest and most lethal form of religious intolerance.

Okoli and Iortyer (2014) said indeed, that since its advent, the sectarian crisis has wrecked immense havoc in the northern Nigeria. It has resulted in the use of explosives and firearms with gruesome, fatal consequences. A critical corollary of this violence is dire humanitarian crisis that threatens human security in Nigeria.

Again, Okoli and Iortyer (2014) noted that apart from the Nigerian Civil War (1967 - 1970), no other single event of complex emergency in the country has been as debilitating as the sectarian crisis in terms of humanitarian impacts. Nonetheless, its humanitarian consequences have grown in terms of scope, degree and diversity. In effect, the humanitarian impacts and implications of the crisis have been historically remarkable and unprecedented.

According to Salkida (2015), since the outbreak of sectarian violence in 2009, the north-east, Borno and Yobe states in particular, has ceased to know civil normalcy. Hate-filled adherents of the extremist sects speed through streets at intervals to shoot down, randomly at their ever widening targets. The above scenario has created an atmosphere of civil siege and volatility. The implication, of this for public peace, safety and security has been critically dire.

The repercussions of the sectarian violence as well as government's counter-violence on the livelihood conditions of the affected states have been disastrous. Owing to public security volatility in these states, normal productive, agricultural and commercial activities have often been constrained. The enforcement of curfews and emergency rule has restricted movement and communications in a manner that hampered economic activities. In addition, the fear of attacks as a result of this sectarian crisis has often driven communities into hiding. The massive destruction of infrastructure, the destruction of telecommunication facilities, frequent attacks on markets and businesses, short business hours, have made many relocate to other safer parts 
of the country, bringing down incomes and increasing poverty levels (Salkida, 2012: para 10).

\subsubsection{Theoretical Framework}

Group theorists like Author Bentley (2015) conceptualizes social activities in terms of groups, according to him, groups are indispensable, some admit that though individuals have roles to play, their roles are more important only in a group context. The theorists see group behavior as relationship between the individuals that constitute such groups. The group one belongs to affects a certain extent of behavior. The sectarian crisis in northern Nigeria therefore, is a conglomerate of interest groups. It is important to note that there are various groups that interplay with each one other in the process of sectarian conflict in Nigeria. According to Bentley's analysis of Group theory, individuals are important only in the group context. Bentley and Shills, see the social system as being made up of groups which compete for values of the society. Consequently, these groups compete for values, attention and demands from the society

Drawing from the subject matter, these groups are being motivated by the activities of the other groups for instance; the Niger Delta Militant group motivated and gingered up Boko Haram sect. Presently, the Boko Haram sect, with its own group interest has turned out to become one of the most terrifying and strongest terrorist groups in Nigeria among other groups. But the group is seen by everybody in and outside the country as a group with special and one sided interest and they fight other groups as well as stand out in relations to no other.

Since group regulate group struggles, they invariably determine peace and stability, sectarian conflict in Nigeria is therefore seen as the result of interplay of demand and objectives of various groups as in the case of Boko Haram Sect and Niger Delta Militant group. In the study of group activities and their influence with its application to terrorist activities in Nigeria, certain variables can be utilized; such variables are the group access to the conflict and instability in the country, group cohesion, the organization of the group, status of the group, leadership, funds and resources. In this analysis, the group theory will be applied in the conflicts and instability of various groups, take for instance, the organization of the Boko Haram sect is based on interplay of groups. There must be leadership for dissemination of information.

\section{Methodology}

\subsection{Data Presentation and Results}

For the purpose of this study, 100 questionnaires were distributed and administered, both in the 2 local governments areas in Kaduna state (Jema'a and Zagon kataf). These 100 respondents were randomly selected but 99 were returned back.

Data Presentation for Research Question One: To what extent does sectarian crisis occur in northern Nigeria? 
Table 1. Respondents views on extent of sectarian crisis occurrences in Northern Nigeria?

\begin{tabular}{lllllllll}
\hline SN & Item statement & SA & A & U & D & SD & MEAN & REMARK \\
\hline 1 & Sectarian Crisis occurred in northern Nigeria & $2 \%$ & $70 \%$ & 14 & $3 \%$ & $9 \%$ & 3.5714 & A \\
2 & Kaduna state is worst hit by sectarian crisis & $3 \%$ & $13 \%$ & 49 & $31 \%$ & $2 \%$ & 2.8600 & A \\
3 & All crisis in Kaduna are sectarian in nature & $41 \%$ & $39 \%$ & $5 \%$ & $3 \%$ & $10 \%$ & 4.000 & A \\
4 & $\begin{array}{l}\text { There are boko Haram members in Kaduna } \\
\text { state }\end{array}$ & $32 \%$ & $51 \%$ & $2 \%$ & $13 \%$ & $0 \%$ & 4.3500 & \\
\hline
\end{tabular}

\section{Results for Research Question One}

NB: The calculated mean will be rejected if it is less than 3 and it will be accepted if it is greater than 3.

Analysis of table one: shows that $72 \%$ of the respondents agreed that Sectarian crisis occurred in Northern Nigeria, $14 \%$ where undecided, while $12 \%$ disagreed. The calculated mean is 3.5714 which is greater than 3 therefore it was accepted. In item two $16 \%$ of respondents agreed that Kaduna state is worst hit by sectarian crisis, $49 \%$ are undecided while $33 \%$ disagree. Therefore, the calculated mean is 2.8600 which is less than 3 therefore it was rejected. In item three: $80 \%$ of the respondents agreed that all crises in Kaduna state are sectarian in nature and 5 respondents where undecided, while 13 respondents disagreed therefore the calculated mean is 4.000 . In table four $83 \%$ of respondents agreed that there are Boko Haram members in Kaduna state, $2 \%$ undecided while $13 \%$ disagreed. The calculated mean is 4.3500 which is greater than 3 therefore it was accepted.

Data Presentation for Research Question Two: What are the remote and immediate causes of sectarian crisis in Nigeria?

Table 2. Respondents views on remote and immediate causes of sectarian crisis in Northern Nigeria

\begin{tabular}{lllllllll}
\hline S/N & ITEM STATEMENT & SA & A & U & D & SD & MEAN & REMARK \\
\hline 5 & $\begin{array}{l}\text { Religion is the major cause of sectarian crisis } \\
\text { in Kaduna state }\end{array}$ & $62 \%$ & $23 \%$ & $5 \%$ & $3 \%$ & $5 \%$ & 3.7200 & A \\
6 & $\begin{array}{l}\text { Political manipulation is also a factor in } \\
\text { sectarian crisis in Kaduna state }\end{array}$ & $7 \%$ & $71 \%$ & $6 \%$ & $13 \%$ & $1 \%$ & 3.6200 & A \\
7 & $\begin{array}{l}\text { Sectarian crisis is also caused by ethnic } \\
\text { differences }\end{array}$ & $21 \%$ & $45 \%$ & $5 \%$ & $27 \%$ & $0 \%$ & 3.9500 & A \\
8 & $\begin{array}{l}\text { Socio-economic (poverty) situation also fuels } \\
\text { sectarian crisis }\end{array}$ & $21 \%$ & $45 \%$ & $4 \%$ & $28 \%$ & $0 \%$ & 3.7300 & A \\
9 & $\begin{array}{l}\text { High rate of illiteracy is also responsible for } \\
\text { sectarian crisis }\end{array}$ & $28 \%$ & $49 \%$ & $13 \%$ & $4 \%$ & $4 \%$ & 3.7100 & A \\
\hline
\end{tabular}

\section{Results for Research Question Two}

NB: The calculated mean will be rejected if it is less than 3 and it will be accepted if it is greater 
than 3.

Analysis of table two: item five shows that $85 \%$ of the respondents agreed that religion is the major cause of sectarian crisis in Kaduna state, $5 \%$ where undecided, while $5 \%$ disagreed: the calculated mean is 3.7200 which are greater than 3 therefore, it was accepted. In item six $78 \%$ of the respondents agreed that Political manipulation is also a factor of sectarian's crisis in Kaduna state, $6 \%$ are undecided, while $14 \%$ disagreed: the calculated mean is 3.6200 which is greater than 3 therefore, it was accepted. In item seven, $66 \%$ of respondents agreed that Sectarian crisis is also caused by ethnic differences, $5 \%$ undecided while, $27 \%$ disagreed. Therefore the mean calculated is 3.9500. In item eight $66 \%$ of the respondents agreed that socio-economic (poverty) situation also fuel sectarians crisis, $4 \%$ are undecided while, $28 \%$ disagreed. In item nine $77 \%$ of respondents agreed that high rate of illiteracy is also responsible for sectarian crisis in Kaduna state, $13 \%$ are undecided while $8 \%$ disagree. The calculated mean is 3.7100 which is greater than 3 therefore, it was rejected.

Data Presentation for Research Question Three: to what extent are efforts made towards conflict prevention in Northern Nigeria?

Table 3. Respondents views on attitude of people towards the activities of civil society organization in Nigeria

\begin{tabular}{lllllllll}
\hline S/N & ITEM STATEMMENT & SA & A & U & D & SD & MEAN & REMARK \\
\hline 10 & Government have measures & $29 \%$ & $41 \%$ & $10 \%$ & $8 \%$ & $10 \%$ & 3.7100 & $\mathrm{~A}$ \\
11 & $\begin{array}{l}\text { put in place to prevent crisis } \\
\text { Government always ignore early warnings in } \\
\text { crisis situation }\end{array}$ & $25 \%$ & $46 \%$ & $4 \%$ & $19 \%$ & $4 \%$ & 3.7400 & $\mathrm{~A}$ \\
12 & $\begin{array}{l}\text { Government efforts in conflict management } \\
\text { always failed }\end{array}$ & $30 \%$ & $40 \%$ & $2 \%$ & $16 \%$ & $10 \%$ & 3.7000 & $\mathrm{~A}$ \\
13 & $\begin{array}{l}\text { Religion bodies have contributed significantly } \\
\text { in maintaining peaceful coexistence and } \\
\text { tolerance }\end{array}$ & $21 \%$ & $60 \%$ & $13 \%$ & $4 \%$ & $0 \%$ & 3.9000 & $\mathrm{~A}$ \\
\hline
\end{tabular}

\section{Results for Research Question Three}

NB: The calculated mean will be rejected if it is less than 3 and it will be accepted if it is greater than 3.

Analysis of table three: item ten shows that $70 \%$ of the respondents agreed that Government have measures put in place to prevent crisis, $10 \%$ where undecided, while $18 \%$ disagreed: the calculated mean is 3.7100 which is greater than 3 therefore, it was accepted. In item eleven it was revealed that $71 \%$ of the respondents agreed that government always ignores early warnings in crisis situation, $4 \%$ where undecided, while $23 \%$ disagreed: the calculated mean is 3.7100 which is greater than 3 therefore, it was accepted. In item twelve, it was revealed that $70 \%$ of the respondents agreed that government's efforts in conflict management always failed, $2 \%$ where undecided, while $26 \%$ disagreed: the calculated mean is 3.7100 which is greater than 3 therefore, it was accepted. 
In item thirteen, it was revealed that $81 \%$ of the respondents agreed that religious bodies have contributed significantly in maintaining peaceful coexistence and tolerance, $13 \%$ where undecided, while $4 \%$ disagreed: the calculated mean is 3.9000 which is greater than 3 therefore, it was accepted.

Data Presentation for Research Question Four: In what ways can Nigeria citizens help in tackling sectarian crisis?

Table 4. Respondents views on possible solution and recommendations toward improving the effort of civil society organization on conflict management

\begin{tabular}{lllllllll}
\hline S/N & ITEM STATEMMENT & SA & A & U & D & SD & MEAN & REMARK \\
\hline 14 & $\begin{array}{l}\text { Sectarian crisis can be resolved in Kaduna state } \\
\text { when people give proper information to the } \\
\text { security agency. }\end{array}$ & $42 \%$ & $7 \%$ & $1 \%$ & $1 \%$ & 4.0000 & A \\
15 & $\begin{array}{l}\text { Security agencies can only succeed when they } \\
\text { have good intelligent gathering. }\end{array}$ & $37 \%$ & $44 \%$ & $7 \%$ & $8 \%$ & $0 \%$ & 4.3500 & A \\
\hline
\end{tabular}

\section{Results for Research Question Four}

NB: The calculated mean will be rejected if it is less than 3 it will be accepted if it is greater than 3.

Analysis of table four: item fourteen shows that $90 \%$ of the respondents agreed that sectarian crisis can be resolved in Kaduna when the people give proper information to the security agencies, $7 \%$ were undecided, while $2 \%$ disagreed: the calculated mean is 4.0000 which is greater than 3 therefore, it was therefore accepted. Item fifteen shows that $83 \%$ of the respondents agree that security agencies can only succeed when they have good intelligent gathering, 7\% where undecided, while $8 \%$ disagreed: the calculated mean is 4.3500 which is greater than 3 therefore, it was accepted.

\section{Discussions}

This study explored the effect of sectarian crisis in Nigeria and it was discovered that the crisis led to serious humanitarian problems. The study observed that sectarian crisis had resulted in dire humanitarian consequences in Nigeria. These consequences include human casualties, fatalities, population displacement and refugee debacle, human rights abuses, livelihood crisis, as well as public insecurity.

In the light of the foregoing, and from the data presented above, the study summit that sectarian crisis constitutes an authentic threat to the national security in Nigeria; hence the need to devise a means of ensuring pragmatic solutions to it. In this regard, the study recommended a shift from anti-sectarianism to strategic anti-sectarianism as the way forward.

Strategic anti-sectarianism presumes combating terrorism through preventive and mitigates measures. This emphasizes the use of strategic intelligence, pragmatic policies and proactive strategies to counter the sectarian group's designs in an attempt to mitigate terror. This 
approach to dealing with sectarian defers from the traditional anti-terrorism campaign, whereby terror is confronted by way of reactive and hyper-defensive competency.

Effective counter-insurgency must be predicated on strategic intelligence and reconnaissance. It is not enough to deploy troops to combat the insurgents on the field; it is much more convenient to engage the insurgents proactively by way of systematic surveillance and reconnoitering in an attempt to stop them before they strike.

Research findings revealed that sectarian crisis occurred in northern Nigeria and Kaduna state is worst hit by this very crisis. Also it pointed out that all crises in Kaduna state are sectarian in nature, majority of the respondents also agreed that there are Boko Haram members in Kaduna state. The research further showed that religion is the major cause of sectarian crisis in northern Nigeria, political manipulation, ethnic differences and socio-economic problems (poverty) and high rate of illiteracy are contributing factors of sectarian crisis in Kaduna state.

The study also revealed that government have measures put in place to prevent crisis and also the government usually ignore early warnings in crisis situations and their efforts in conflict management always failed however, religious bodies have contributed significantly in maintaining peaceful coexistence and tolerance.

The findings indicated that sectarian crisis can be resolved in Kaduna when the citizens give proper information to the security agencies, indicating that these agencies can only succeed when they have good intelligent gathering and that government should create laws to curb religious extremism.

\section{Conclusions}

This study explored the effect of sectarian crisis in Nigeria and discovered that the crisis led to serious humanitarian problems. The study observed that sectarian crisis has resulted in dire humanitarian consequences in Nigeria. These consequences include human casualties, fatalities, population displacement and refugee debacle, human rights abuses, livelihood crisis, as well as public insecurity.

The study concluded that sectarian crisis constitutes an authentic threat to the national security in Nigeria; hence there is a need to devise a means of ensuring a pragmatic solution to it. In this regard, the study recommended a shift from anti-sectarianism to strategic anti-sectarianism as the way forward.

Strategic anti-sectarianism presumes combating terrorism through preventive and mitigating measures. This emphasizes the use of strategic intelligence, pragmatic policies and proactive strategies to counter the sectarian group's designs in an attempt to mitigate terror. This approach to dealing with sectarian defers from the traditional anti-terrorism campaign, whereby terror is confronted by way of reactive and hyper-defensive competency.

Effective counter-insurgency must be predicated on strategic intelligence and reconnaissance. It is not enough to deploy troops to combat the insurgents on the field; it is much more convenient to engage the insurgents proactively by way of systematic surveillance and reconnoitering in an attempt to stop them before they strike. 
It can be concluded that sectarian violence contaminate social relations and undermines the economy of the state. Ethno religious intolerance in Nigeria has become a hinge of various forms of nationalism ranging from assertion language, cultural autonomy and superiority to demands for local political autonomy and self determination. The realities of sectarian conflict in Nigeria are alarming and require very urgent and continued attention. The use of ethnicity, religious and politics should rather unite us as Nigerians in order to promote peace, harmonious peaceful co-existence and unity. The reverse of this has consequences for Nigeria as there have been cases where 'ethno-religious' conflicts had claimed so many lives and property hence, it can be concluded that there is a negative effect of sectarian crisis in northern Nigeria and there are significant efforts made towards preventing conflict in this very part of the Nigerian state.

Based on the research findings, the following recommendations are made.

1. Compulsory Regulation of Religious activities: As a regulatory measure, religious leaders should be screened, registered and granted license to preach. They must commit themselves to non-violence act while their constitutional rights to freedom of speech and association are guaranteed. Religion should be used to promote institutional integration instead of otherwise. Religion should be given its proper place in national life proportionate with our historical situation. It should be seen purely as the private affair of an individual based on his or her convictions, not forced on him or her.

2. Literacy level: The level of literacy in the northern part of Nigeria is very high. This is because the north despite the vast resources at its disposal has not shown enough commitment necessary to turn around the educational sector. Regrettably, the zone has the highest school drop-out rate in the country. Most of these school drops-out in their bid to survive turn to menial jobs as means of livelihood. Some of these drops-outs eventually graduate to become miscreants in most cases that serve as the willing tools in many sectarian conflicts in the country. Therefore there is need for government policy to place priority on the nation's educational development.

3. Strengthening of government machinery: Government should strengthen its machinery to enforce the implementation of probe panel reports, so as to prevent criminal impunity on the side of the offenders and their sympathizers. On treating the reports of the probe panel on any ethno religious conflict, government should ensure that there is no sacred cow in the administration of justice.

4. Religious communities must educate their clergy: All religious leaders are to educate their members on the need for peaceful co-existence and tolerance in the society. They should be taught that violence is the last resort in every dispute. And they should be taught the consequences of crisis in the society and its effect on the economy.

5. Collaboration with Security Agencies. Security personnel alone can hardly uproot the terrorist menace in parts of the world and Nigeria in particular. Essentially the security agencies need the co-operation of all citizens to solve the present security challenges through giving of prompt and reliable information, exposing the identity of the perpetrators of crimes in their communities and funding or provision of logistics. Security therefore is everybody's business. Let all hands be on deck to secure ourselves and our society. Government should improve or rather upgrade its intelligence gadgets 
and surveillance equipments. This can be used in monitoring the activities or other changing information, which could be done through closed-circuit television, internet traffic, and social network analysis and biometric.

\section{References}

Abu-Nimer, M. (2000). Conflict resolution, culture and religion: Toward a Training model of inter-religious peace building. Journal of Peace Research, 38(6), 685-704.

Achunike, H. C. (2007). Religious practices in Nigeria as a source of social conflict. A Seminar paper presented on June 10th - 13th at St. Thomas of Aquinas Major Seminary, Makurdi.

Adeniyi, M. O. (1993). Religion and Politics: An Eye Bird's View of Development in Nigeria. In R. D. Abubakar (Eds.), Religion and Politics in Nigeria. Ilorin: NASR

Aleyomi, M. B. (2012). Ethno-Religious Crisis as Threat to the Stability of Nigeria Federal.

Alisan, Y. O. (2000). Ethnicity and Religion: What Impact on Democracy? A Paper Presented at a Round Table Workshop on Ethnicity and Religious Rights in Nigeria Organized by Human Rights Monitor in Kaduna From 13 - 14, December 2000.

Asaju, D. (1988). The Christian position on the Development of Ethical Values in the Nigerian Context. Ilorin: Amora Press Ltd.

Awake. (2008). “When terrorism will end”. June edition, pp. 1-6.

Bagaji, A. S. Y. (2012). Boko Haram and the Recurring Bomb Attacks in Nigeria: Attempt to impose Religious Ideology through Terrorism. Cross-Cultural Communication, 8(1), 33-41.

Balogun, K. A. (1988). Religious intolerance as a source of national disintegration. In: Mala, Sam B. ed. Religion and national unity. Ibadan, University Press.

Barga, T. (2012). Towards a theology of peace: A panacea to terrorism and violence. Jos Studies, 20, 1-24.

Bentley, A. (1908). The Process of Government. Chicago: University of Chicago Press.

Creeping Sharia (2010). Reports and comments. Retrieved November 1, 2011, from http://creepingsharia.wordpress.com/2010/03/08/nigeria-muslims-slaughter-400-500-christian s-in-latest-joscrisis/

Crisis Group. (2010). Northern Nigeria: Background to Conflict Africa Report N 168, 20 December.

Danjibo, N. D. (n.d.). Islamic fundamentalism and sectarian violence: The 'Maitatsine' and 'Boko Haram' crises in northern Nigeria. Peace and conflict studies programme, Institute of African Studies, University of Ibadan. Retrieved October 23, 2011, from http://www.ifranigeria. org

Fayemi, K. (2003). Preventing Conflict and Promoting Peace and Security within NEPAD and 
African Union- some preliminary comments. In E. Obadare \& D. Oyewole (eds.), The New Partnership for Africa's Development (NEPAD): Challenges and Development (pp. 63-83). London: Centre for Democracy and Development (CDD).

Fisher, R., \& Ury, W. (1991). Getting to yes: Negotiating agreement without giving in (2nd ed.). New York: Penguin Books.

Gilbert, A. (2000). The proposed Sharia Legal system conflict in Kaduna state. The February 28, pp. 5-8.

Gofwen, R. I. (2004). Religious conflicts in northern Nigeria and nation building: The throes of two decades 1980-2000. Kaduna, Human Rights Monitor.

Hamaza, J. M. (1978). The I found it (Jesus Salvation) demonstration. Newswatch, May 30, 1978 P. 17.

Human Right Watch. (2013). A Report of the Human Rights Watch, October 2013.

Humanitarian Coalition (2013). Retrieved August 06, 2016, from http://humanitariancoalition.org/sites/default/files/factsheett/what-is-ahumanitarian-crisis-en glish.pdf

Juergensmeyer, Mark 2000. Terror in the mind of God: The global rise of religious violence. Berkeley, University of California Press.

Kassim. (1982). The Maitatsine Conflict in Kaduna. Time international, March 10, P. 10 - 11.

Komonchak, J., Mary, C., \& Dermot, A. L. (1993). The new dictionary of theology. Collegeville, MN, The Liturgical Press.

Kukah, Matthew H. (1996). Public perceptions of the press in Nigeria. In: Dare, Olatunji and ournalists, Lagos State Council.

Kwaja, Chris M. A. (2009). Strategies for Rebuilding state capacity to manage ethnic and religious conflict in Nigeria. The Journal of Pan African Studies, 3(3), 105-115.

Lagos-Ibadan Road Crusades. Daily Champion, 27 April.

Lukeman, U. S. (2000). Sharia conflict Reprisal attack on northerners. News watch, March 20, p. 25.

Makarfi, A. M. (2004). Peace Building and Conflict Resolution.

Maregere, T. P (2011). Religion: A source of conflict and a resource for peace. Conflict Trends Issue 1, 2011, pp. 17-23.

Ndagi, A. B. (2000). The phase two Sharia conflict in Kaduna. News watch, July 3 p. 16.

Nigerian Tribune, Monday, August 10, 2009, p. 17.

Okafor, A. O., \& Eloagu, U. O. (2002). National Ethnics and Good Governance. In Lect.

Okolie, A.M (2009), “Capitalist Development Strategies and Poverty Alleviation in Africa”. 
Nigerian Journal of Public Administration and Local Government, XIV(1and 2), 54-68.

Omotosho, A. O. (2003). Religious violence in Nigeria - the causes and solutions: An Islamic perspective. Swedish Missiological Theme, 2003, pp. 15-31.

Osaghae, E., \& Rotimi, T. S. (2005). A history of identities, violence, and stability. In: Nigeria Centre for Research on Inequality, Human Security and Ethnicity (CRISE), Working paper No. 6.

Otuwoyo, S. (2001). Muslim - Christian Clash in Kaduna. The News, Novembers, p. 22.

Ozigbo, R. A. (1993). Religious co-existence in Nigeria: An inquiry and Suggestions in the Nigerian Journal of Theology. Enugu: SNAAP Press.

Raymond, C. T., \& Rajat, G. (2002). Understanding Ethnic Conflict. The international Dimension. New York: Addison-Wesley Educational Publisher.

Sadah, Y. S. (1996). Crises over El-Zakzaky Arrested new Nigeria, April 5, 199 p. 9.

Salawu, B. (2010). Ethno-religious conflicts in Nigeria: Causal analysis and new management strategies. European Journal of Social Sciences, 13(3), 345-353.

Sani, S. (2007). The Killing Fields: Religious Violence in Northern Nigeria. Ibadan Spectrum Shabayany, B. S. (2012). New waves of terrorism in Nigeria not true expression of Islam. Jos Studies, 20, 33-47.

Shabi, O., \& Awe, K. (2001). Understanding Society and Social Relations. Lagos: Concept Publications.

Shehu, S. (2011). Boko Haram: History, Ideas and Revolt. News Diary. Retrieved from http://www.nigeriamasterweb.com

Spero News. (2010). Archbishop says media has inflamed ethnic/religious conflict. 22 January. Retrieved November 26, 2011, from http://www.speroforum.com/a/26054/Nigeria-Archbishop-says-mediahas-enflamed-ethnicreli gious-conflict

Tell, August 10, 2009, p. 34.

Tell, August 17, 2009, p. 69.

The Guardian, Thursday, October 13, 2009, p. 11.

The Nation, Friday, August 14, 2009, p. 1.

The Nation, Monday, August 10, 2009, p. 1.

This Day, Thursday, September 3, 2009, p.1.

This Day, Thursday, September 3, 2009, p.1.

Umar, S. M., \& Anrew, U. (1996). Kaduna Polytechnic Religion concert. The News, June 30, 
1996, pp. 19-20.

Umar, S. M., \& Anrew, U. (1996). Kaduna Polytechnic Religiou concert. The News, June 30, 1996, pp. 19-20.

Umezeh, U. (1996). The Eclipse of the moon conflict in Kaduna. Nigerian Tribune, April 5, p. 4.

Usman, Y. B. (1987). The Manipulation of Religion in Nigeria. Kaduna: Vanguard Printers and Publishers.

Weidmann, N. B. (2002). Violence "From above or From below". The Role of Ethnicity in Bosnia’s Civil War. The Journal of Politics, 73(4), 54.

Yahaya, L. (2011). Ethnic and Religious Conflicts In Kaduna and Plateau States: Implications For Development In Nigeria: A Thesis Submitted To The Department Of Religion \& Cultural Studies, Faculty Of The Social Sciences, University Of Nigeria Nsukka.

Yusuf, S. B. (1980). The Izala/Tijaniya intra-faith clash (p. 3). The Guardian, September 26, 1980.

\section{Copyright Disclaimer}

Copyright for this article is retained by the author(s), with first publication rights granted to the journal.

This is an open-access article distributed under the terms and conditions of the Creative Commons Attribution license (http://creativecommons.org/licenses/by/3.0/). 